\title{
NIKAH SIRRI MENURUT HUKUM ISLAM DAN HUKUM POSITIF
}

\author{
Endang Zakaria ${ }^{1}$, Muhammad Saad ${ }^{2}$ \\ Prodi Hukum Keluarga Islam FAI-UMJ ${ }^{1}$ \\ Prodi Hukum Keluarga Islam FAI-UMJ ${ }^{2}$ \\ Email: end.zakaria@umj.ac.id ${ }^{1}$, muhammad.saad@umj.ac.id ${ }^{2}$
}

\begin{abstract}
Islamic law defines marriage as an absolute obligation to follow Allah's command and carry it out as worship and represents a very strong bond. In the context of unregistered marriage, it can be defined as "a form of marriage based on religious law or custom, as well as one that is not announced to a crowd and is not registered with the marriage registry". This paper discusses literacy in Islamic law and positive law on unregistered marriages. Positive law studies on unregistered marriages are carried out on the essence of the Law of the Republic of Indonesia and Government Regulations. According to Indonesian law, sirri marriage is a marriage that is not based on the principle of legality. In Islam, the study of unregistered marriage was based on Qur'an and hadith. This means that it is not legally binding. A marriage that is in accordance with the pillars and conditions of marriage is valid under Islamic law, as are marriages performed in sirri marriages, as defined in Indonesian law.
\end{abstract}

Keywords : positive law, islamic law, sirri mariages

Abstrak: Pernikahan dalam hukum Islam dispesialisasikan sebagai sebuah bentuk ikatan yang sangat kuat atau mitsaqon ghalidhan untuk mentaati perintah Allah dan melaksanakannya merupakan ibadah. nikah siri dapat didefenisikan sebagai "bentuk pernikahan yang dilakukan secara hukum agama atau secara adat istiadat, dan juga tidak diumumkan pada halayak yang ramai serta tidak dicatatkan secara resmi di kantor pegawai pencatat nikah.Tulisan ini bertujuan untuk mengkaji literasi hukum islam dan hukum positif terhadap nikah siri. Metode dalam penelitian ini yaitu kualitatif deskriptif dengan dokumentasi sebagai teknik pengumpulan data dan analisa deskriptif sebagai teknik analisa data. Kajian hukum positif terhadap nikah siri dilakukan terhadap esensi Undang-undang Republik Indonesia dan Peraturan Pemerintah. Kajian hukum islam terhadap nikah siri dilakukan terhadap Alquran dan hadist. Dalam perspektif hukum positif Indonesia, menurut peraturan perundang-undangan, nikah sirri merupakan pernikahan yang tidak asas legalitas. Dalam arti tidak mempunyai kekuatan hukum.Suatu perkawinan yang dilakukan sah menurut hukum agama, apabila sesuai dengan rukun dan syarat nikah. Begitu juga dengan pernikahan yang dilakukan secara rahasia (nikah siri) dalam pengertian piqh Indonesia.

Kata Kunci : hukum positif, hukum Islam, nikah sirri 


\section{PENDAHULUAN}

Islam adalah agama yang sempurna, yang mengatur segala aspek kehidupan makhluknya baik yang secara lahiriyah maupun bathiniyah. Islam juga sangat memahami situasi dan kondisi manusianya, oleh karena itu tidak ada aktivitas kehidupan manusia didunia ini yang terlewatkan oleh ajaran agama Islam. Sebagai makhluk sosial, manusia butuh teman untuk berinteraksi dan mewujudkan suatu yang diinginkan. Dalam agama Islam disebut juga dengan mu'amalah (yang mengatur kehidupan sosial).

Islam mendorong untuk membentuk keluarga, mengajak manusia untuk hidup dalam naungan keluarga, karena keluarga merupakan gambaran kecil dalam kehidupan sosial yang menjadi pemenuhan keinginan manusia, tanpa menghilangkan kebutuhannya. ${ }^{1}$ Menikah adalah fitrah insani yang mengantarkan manusia pada kebahagiaan dan kedudukan mulia di sisi Allah swt. Seseorang yang akan menikah tentu bercita-cita memiliki keluarga yang harmonis yang dibalut dengan cinta dan kasih sayang, sehingga mendapatkan ketenteraman dan kebahagiaan kehidupan.

Anjuran agama Islam supaya melangsungkan pernikahan dinyatakan dalam berbagai ungkapan yang terdapat dalam Al-Qur'an maupun Al hadist, ${ }^{2}$ di antaranya :

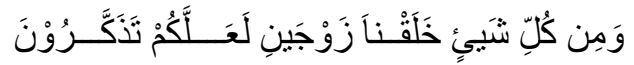

Dan segala sesuatu Kami ciptakan berpasang-pasangan supaya kamu mengingat kebesaran Allah. (Ad-Dzariyyat :49) ${ }^{3}$

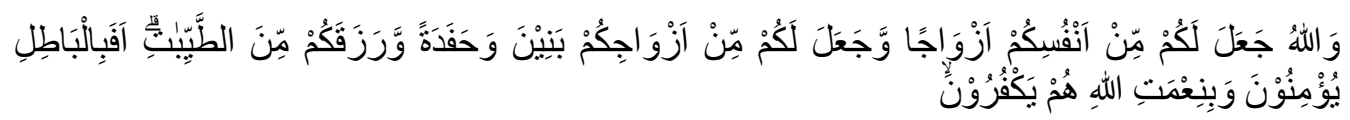

Allah menjadikan bagi kamu isteri-isteri dari jenis kamu sendiri dan menjadikan bagimu dari isteri-isteri kamu itu, anak-anak dan cucu-cucu, dan memberimu rezki dari yang baik-baik. Maka mengapakah mereka beriman kepada yang bathil dan mengingkari nikmat Allah? (QS. An-Nahl: 72).

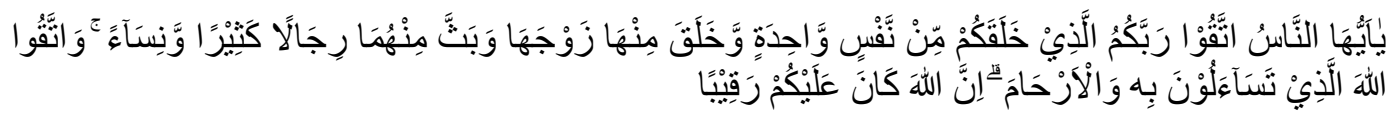

Hai sekalian manusia, bertakwalah kepada Tuhan-mu yang telah menciptakan kamu dari seorang diri, dan dari padanya Allah menciptakan isterinya; dan dari pada keduanya Allah memperkembang biakkan laki-laki dan perempuan yang banyak. Dan bertakwalah kepada Allah yang dengan (mempergunakan) nama-Nya kamu saling meminta satu sama lain, dan (peliharalah) hubungan silaturrahim. Sesungguhnya Allah selalu menjaga dan mengawasi kamu. (QS. An-Nisa': 1)

\footnotetext{
Hal 23.

2 Kamal Mukhtar, “Asas-asas Hukum Islam tentang Perkawinan”, Jakarta 1974.

3 Al Qureean dan Terjamahnya, Mujamma' Al Malik Fahd Li Thiba'at Al Mushaf Asysyarif : Madinah Al Munawwaroh. 1997 Hal 862

${ }^{4}$ Ibid.
}

${ }^{1}$ Ali Yusuf As-Subki, Fiqh Keluarga: "Pedoman Berkeluarga dalam islam”, Jakarta 2010. 
"Wahai para pemuda! Barangsiapa di antara kalian berkemampuan untuk menikah, maka menikahlah, karena nikah itu lebih menundukkan pandangan, dan lebih membentengi farji (kemaluan). Dan barangsiapa yang tidak mampu, maka hendaklah ia shaum (puasa), karena shaum itu dapat membentengi dirinya." (HR Bukhari, Muslim, Tirmidzi, dan lainnya). ${ }^{5}$

Dari ayat diatas dapat ditarik suatu pengertian secara singkat bahwa perkawinan adalah tuntutan kodrat hidup yang dengan tujuan, diantaranya untuk memperoleh keturunan guna untuk melangsungkan hidup. ${ }^{6}$ Menikah dan memiliki keluarga dalam kehidupan merupakan salah satu sunnatuloh terhadap makhluk, yang mana dia merupakan suatu hal yang umum dan mutlak dalam dunia kehidupan hewan maupun tumbuh-tumbuhan.

Pernikahan disyari'atkan oleh Islam sebagai jalan terhormat yang harus ditempuh manusia dalam membentuk keluarga. Melalui pernikahan, umat manusia membangun keluarga yang bahagia, sejahtera untuk mengisi dan memakmurkan dunia ini dengan tuntunan dan ajaran dari Allah SWT. Manusia yang menyalurkan kebutuhan biologisnya tanpa melalui pernikahan berarti telah rela melepaskan dirinya dari eksistensi kemanusiaannya selaku makhluk yang paling utama, dan terjerumuslah ia kelembah hidup hewani yang rendah, bahkan lebih hina dari hewan. ${ }^{8}$

Pernikahan dalam hukum Islam dispesialisasikan sebagai sebuah bentuk ikatan yang sangat kuat atau mitsaqon ghalidhan untuk mentaati perintah Allah dan melaksanakannya merupakan ibadah. Oleh karena demikian pentingnya perkawinan atau pernikahan, maka ia harus dilakukan menurut ketentuan hukum Islam dan oleh karena itu keberadaannya perlu dilindungi oleh hukum Negara sesuai dengan peraturan perundang-undangan yang berlaku agar perkawinan tersebut mempunyai kekuatan hukum. ${ }^{9}$ Upaya yang dilakukan dalam melindungi tujuan dari pernikahan itu tidak dapat dianggap remeh, sebab waktu yang lama.

Perkawinan sirri dalam pandangan hukum positif Indonesia tidak sah dan tidak dapat dibenarkan berdasarkan UU Perkawinan Pasal 2 Ayat 2 dan pelaksanaannya terdapat dalam PP No 9 Pasal 2 Ayat 2 Secara garis besar keberadaan perkawinan yang tidak dicatatkan berarti telah membiarkan adanya seorang laki-laki dan perempuan yang hidup bersama diluar perkawinan, dan ini sangat merugikan para pihak yang terlibat (terutama perempuan), terlebih lagi kalau mereka sudah memiliki anak-anak yang dilahirkan dari hubungan diluar nikah.

Nikah sirri berasal dari Bahasa Arab yang dikenal dengan zawaj as-sirri yaitu: pernikahan yang dilakukan secara rahasia. Pernikahan sirri yang dikenal di kalangan masyarakat luas ada dua: Pertama: pernikahan tanpa wali. Pernikahan yang semacam ini dilakukan secara rahasia, karena wali perempuan tidak setuju atau karena menganggap sah pernikahan tanpa wali atau hanya semata-mata ingin

\footnotetext{
${ }^{5}$ https://detil.co/hadis-pernikahan-yang-perlu-diketahui. Diunduh tgl 08/03/2021 jam 9;30

${ }^{6}$ Ahmad Azhar Basyid : Hukum Perkawinan Islam, cetakan 12 Yogyakarta, 2010. Hal 11

7 Sekh Muhammad bin Ibrahim at-Tuaijri: Ringkasan Fikih Islam, terjemahan team Indonesia Islam house.com, 2009. hal 3.

${ }^{8}$ K.H. Ibrahim Husen: Membina Keluarga Bahagia, Bab 4 Konsepsi Pembentukan Keluarga Bahagia dalam Islam. Jakarta, 1993 hlm. 33

9 http://www.pa-rembang.go.id/9-artikel/90-fenomena-nikah-sirri-dalam-sebuah-negarahukum-indonesia-dewasa-ini.html
} 
kepuasan nafsunya saja. Kedua: pernikahan yang sah secara agama, namun tidak diumumkan secara luas dan tidak pula dicatatkan dalam lembaga negara yang berwenang. ${ }^{10}$

Pernikahan sirri yang dilakukan oleh sebagian masyarakat, disebabkan kurangnya pengetahuan masyarakat tentang pernikahan. Bermacam alasan yang melatarbelakangi seseorang melakukan nikah siri. Ada yang menikah karena terbentur ekonomi, sebab sebagian pemuda tidak mampu menanggung biaya pesta, menyiapkan rumah milik sendiri dan harta gono gini, maka mereka memilih menikah dengan cara misyar yang penting halal, hal ini terjadi di sebagian besar Negara Arab. Ada juga yang tidak mampu mengeluarkan dana untuk mendaftarkan diri ke KUA yang dianggapnya begitu mahal. Atau malah secara finansial pasangan ini cukup untuk membiayai, namun karena khawatir pernikahannya tersebar luas akhirnya mengurungkan niatnya untuk mendaftar secara resmi ke KUA atau catatan sipil. Hal ini untuk menghilangkan jejak dan bebas dari tuntutan hukum dan hukuman administrasi dari atasan, terutama untuk perkawinan kedua dan seterusnya (bagi pegawai negeri dan TNI). Dan ada pula dari sebagian masyarakat melakukan nikah siri dengan mengkriminalisasikan nikah siri, dengan tujuan untuk menutupi aib seseorang seperti seseorang yang ingin poligami tapi takut diketahui oleh istrinya. Atau karena seorang wanita yang hamil diluar nikah. Mereka yang melakukan nikah siri factor yang jadi dominan mereka yang menikah sirri atau di bawah tangan adalah masalah seperti prosedural yang tak bisa terpenuhi. ${ }^{11}$

\section{METEDOLOGI PENELITIAN}

Penelitian ini difokuskan kepada kepustakaan (library research) yaitu mencari teori-teori dan konsep-konsep yang dijadikan landasan penelitian. Penelitian ini menggunakan pendekatan kualitatif. Penelitian ini juga menggunakan jenis penelitian deskriptif. Penelitian deskriptif merupakan penelitian yang berusaha mendeskripsikan dan menginterpretasikan data yang ada, di samping itu penelitian deskriptif terbatas pada usaha mengungkapkan suatu masalah atau dalam keadaan ataupun peristiwa sebagaimana adanya, sehingga bersifat sekedar mengungkapkan fakta (fact finding). Penelitian ini di mulai dari fakta empiris, yang bertujuan untuk mendapatkan gambaran yang faktual, obyektif, utuh, mengenai masalah dalam penelitian ini.

Metode dukumentasi adalah metode penelitian untuk memperoleh keterangan dengan cara memeriksa dan mencatat laporan dokumen yang ada. Menurut Djumhur dan Muhammad Surya, metode dokumentasi adalah metode pengumpulan data yang telah didokumentasikan dalam buku-buku yang telah tertulis seperti, buku induk, buku pribadi, surat keterangan dan sebagainya.

Setelah berbagai data terkumpul, maka untuk menganalisanya digunakan teknik analisa deskriptif, artinya peneliti berupaya menggambarkan kembali datadata yang terkumpul mengenai gambaran secara mendalam tentang perkembangan hukum nikah sirri menurut perspektif hukum Islam. ${ }^{12}$

\footnotetext{
${ }^{10}$ Musthafa Luthfi dan Mulyady Luthfy : nikah sirri, Surakarta 2010.

${ }^{11}$ Aris Sugianto: Nikah Bawah Tangan, Jakarta 2005

${ }^{12}$ Suharsimi Arikunto: Prosedur Penelitian, Yogyakarta 2010. Hlm. 282
} 


\section{HASIL DAN PEMBAHASAN}

\section{Perkawinan dalam Perspektif Hukum Positif Indonesia}

Dalam bahasa Indonesia istilah pernikahan sering disebut juga perkawinan. Perkawinan berasal dari kata "kawin" yang menurut bahasa artinya membentuk keluarga dengan lawan jenis; bersuami atau beristeri; melakukan hubungan kelamin atau bersetubuh. ${ }^{13}$

Hukum perkawinan dalam Islam sebagai bagian integral dari syari'ah Islam tidak dapat dipisahkan dari Islam. Dalam kehidupan masyakat Islam, norma atau kaidah yang terkandung dalam agama Islam diimplementasikan dalam bentuk aturan pokok yang disebut syri'at perkawinan Islam. Allah Swt mewajibkan umat Islam melaksanakan syari'at Islam dalam kehidupan fribadi, bermasyarakat, dan bernegara, terutama melakukan perkawinan. Upaya mewujudkan perkawinan Islam dalam system hukum positif Indonesia memerlukan proses formulasi kedalam bentuk aturan perundang-undangan. Formulasi tersebut merupakan perjuangan masyarakat Islam sehingga mampu menempatkan hukum perkawinan Islam dalam bentuk undang-undang yang mengikat sebagai bagian dari sistem hukum positif Indonesia. Perjuangan tersebut tidaklah mudah memerlukan waktu yang sangat lama.

Selama tiga dasawarsa terakhir beberapa aturan syari'at perkawianan Islam yang telah menjadi bagian dari system hukum positif Indonesia, antara lain:

1 Undang-undang Nomor 1 tahun 1974 tentang Perkawinan,

2 Undang-undang Nomor 7 tahun 1989 jo. tentang Peradilan Agama,

3 Peraturan Pemerintahan Nomor 9 tahun 1975 tentang Pelaksanaan

Undang-undang Nomor 1 tahun1974 tentang Perkawinan.

4 Peraturan Pemerintah Nomor 45 tahun1990 tentang Perkawinan dan Perceraian bagi Pegawai Negeri Sipil.

Perjuangan umat Islam dalam mewujudkan peraturan perkawinan Islam sebagai bagian dari hukum normatif dalam sistem hukum positif Indonesia tidak boleh dianggap remeh dan sudah cukup berarti, apabila secara normatif sudah cukup kuat status hukum perkawinan Islam dalam berbagai kegiatan hidup bermasyarakat, yang perlu diperjuangkan dalam kehidupan nyata adalah aktivitas mewujudkannya dalam prilaku mulia yang diridhoi allah Swt.

\section{Hukum Nikah Siri Menurut Perspektif Hukum Islam}

Kata "sirri" dalam istilah nikah sirri berasal dari Bahasa arab yaitu :"sirrun" yang artinya rahasia. Melalui kata ini, nikah sirri diartikan sebagai pernikahan yang dirahasiakan. berbeda dengan nikah pada umumnya yang dilakukan secara terang-terangan. Oleh karena itu, nikah siri dapat didefinisikan sebagai "bentuk pernikahan yang dilakukan secara hukum agama atau secara adat istiadat, dan juga tidak diumumkan pada halayak yang ramai serta tidak dicatatkan secara resmi di kantor pegawai pencatat nikah. ${ }^{14}$

Dalam hukum Islam pernikahan diatur sesuai dengan perintah yang terdapat dalam Al-Qur'an dan al-Hadist, yang biasanya dikenal dengan fiqh munakahat. Dalam kitab-kitab fiqh klasik tidak banyak yang menerangkan secara khusus tentang permaslahan nikah siri. karena pada masa nabi Muhammad SAW yang popular dan umum adalah pernikahan yang biasa (jahri). Pernikahan adalah

\footnotetext{
${ }^{13}$ Departemen Pendidikan Nasional, Kamus Besar Bahasa Indonesia, Edisi Ketiga, Jakarta, Balai Pustaka, 2001.

${ }^{14}$ Happy Susanto: Nikah Sirri Apa Untungnya?. Jakarta: Visi Media, 2007 hlm. 22
} 
sebuah kontrak yang serius dan juga moment yang sangat membahagiakan dalam kehidupan seseorang, maka dianjurkan untuk mengadakan sebuah pesta perayaan pernikahan (walimatul 'urs), serta membagi kebahagiaan itu dengan orang lain. Seperti dengan para kerabat, teman-teman ataupun bagi mereka yang kurang mampu. Dan pesta perayaan pernikahan juga sebagai rasa syukur kepada Allah SWT atas segala nikmat yang telah Dia berikan kepada kita. Sebagaimana sabda Nabi Muhammad SAW :

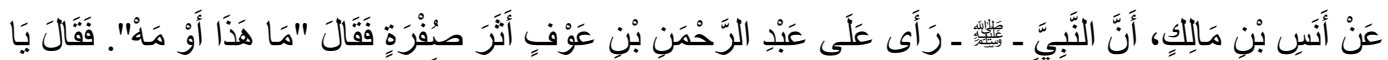

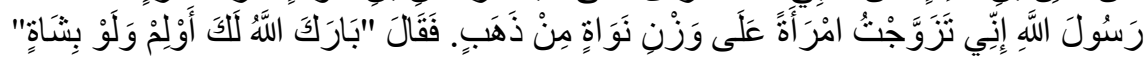

Dari Anas Ibnu Malik Radliyallaahu 'anhu bahwa Nabi Saw pernah melihat bekas kekuningan pada Abdurrahman Ibnu Auf, Lalu beliau bersabda: "Apa ini?". Ia berkata: Wahai Rasulullah, sesungguhnya aku telah menikahi seorang perempuan dengan maskawin senilai satu biji emas. Beliau bersabda: "Semoga Allah memberkahimu, selenggarakanlah walimah walaupun hanya dengan seekor kambing”. (Muttafaq Alaihi dan lafadznya menurut Muslim). ${ }^{15}$

Di samping itu dengan adanya walimah dalam perkawinan memiliki fungsi yaitu mengumumkan kepada khalayak ramai tentang pernikahan itu sendiri. Karena Tidak ada cara lain yang lebih baik untuk menghindari zina melainkan melalui pernikahan. Rasulullah SAW mengajarkan kita bahwa sudah menjadi kewajiban seorang muslim untuk menjawab undangan pernikahan dan bahkan Rasulullah SAW menekankan untuk menghadiri undangan/ walimah, dengan catatan dalam walimah tersebut tidak ada sesuatu kemungkaran. Sebagaimana hadist nabi yang berbunyi :

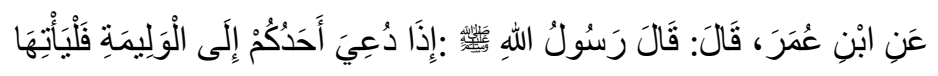

Dari Ibnu Umar Radliyallaahu 'anhu bahwa Rasulullah Shallallaahu 'alaihi wa Sallam bersabda: "Apabila seorang di antara kamu diundang ke walimah, hendaknya ia menghadirinya." (Muttafaq Alaihi. menurut Riwayat Muslim) $)^{16}$

Dalam walimah disunnahkan untuk mengundang orang-orang saleh, baik mereka yang miskin ataupun kaya, termasuk sunnah pula dengan merayakannya tiga hari setelah pasangan berkumpul, sebagaimana dibolehkannya menghidangkan apa saja dari makanan halal. Sebuah walimah akan menjadi haram jika yang diundang hanya orang-orang kaya saja, tanpa mengundang orang-orang miskin. ${ }^{17}$ Maka para ulama berpendapat bahwa seseorang boleh untuk tidak menghadiri pernikahan hanya dengan alasan-alasan yang diperbolehkan menurut Islam.

Namun demikian, ada juga sebagian orang melakukan pernikahan itu dengan cara diam-diam, tanpa harus diketahui oleh orang banyak yang biasa

15 Ibnu Hajar Al-Asqolani, Bulugh Al-Marom min Adhillatil Ahkam : Terjemah, Kitab Nikah. Shahih, Jakarta, 2016, Hal 507

${ }^{16}$ Ibid, hlm. 512

17 Sekh Muhammad bin Ibrahim at-tuaijri : Ringkasan Fikih Islam, terjemahan Team Indonesia Islam house.com, 2009. Hal 23 
disebut dengan nikah sirri. Dengan suatu alasan yang tidak dibenarkan dalam agama Islam. Hal ini sangat ditentang oleh para ulama dan imam mazhab karna mereka menganggap ini menyalahi aturan dan perkawinannya tidak sah. ${ }^{18}$

Atas dasar ini Syaikh Siapul Muaidah. mengatakan jumhur ulama mengatakan bahwa pernikahan belum dianggap sah kecuali diumumkan secara terang-terangan, atau belum sah kecuali dihadiri oleh wali dan saksi saat ketika akad nikah berlangsung, meskipun penyiarannya secara sederhana. ${ }^{19}$

Mengumumkan pernikahan dapat menghindarkan pasangan suami-istri dari kemudratan. Pernikahan yang sengaja dirahasiakan dapat menggiring persepsi masyarakat pada dugaan yang negatif, seperti dugaan kumpul kebo, perselingkuhan, perzinahan dan lain sebagainya.

Salah satu rukun nikah yang menjadi titik permasalahan dalam nikah siri adalah masalah perwalian dan saksi. Sudah menjadi kesepakatan umum di kalangan ulama bahwa pernikahan tanpa adanya wali dan 2 orang saksi, maka pernikahannya tidah sah. Prinsip hukum ini didasarkan pada hadis Nabi Saw:

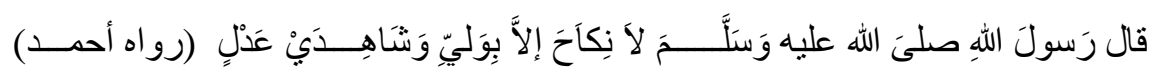

Artinya : Tidak sah suatu pernikahan tanpa adanya wali dan dua orang saksi yang adil. $\left(\right.$ HR. Ahmad). ${ }^{20}$

Pentingnya posisi wali dalam suatu pernikahan tidak dapat ditawar-tawar lagi. Berdasarkan Hadits Nabi menyebutkan dari 'Aisyah RA. Rasulullah bersabda : Siapapun yang menikah tanpa wali, maka nikahnya batal (HR. Empat Imam kecuali Nasa'i).

Dari ketentuan hadits di atas, posisi wali sangatlah penting karena merupakan rukun yang menentukan sah tidaknya pernikahan. Walaupun beberapa kalangan ulama ada yang membolehkan (mensahkan) pernikahan tanpa adanya wali, seperti Abu Hanifah, zufar dan zuhri yang cendrung berpendapat bahwa pernikahan perempuan tanpa adanya wali maka pernikahannya sah, selama pasangan sekufu (setara) dengannya. Pendapat mereka ini dipahami dari Al Qur'ean Al-Baqarah ayat 234 :

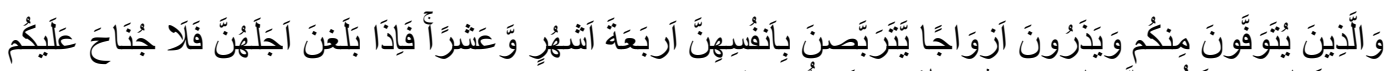

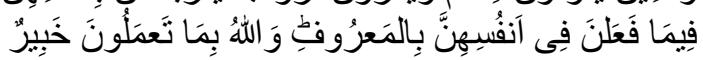

Orang-orang yang meninggal dunia di antaramu dengan meninggalkan isteri-isteri (hendaklah para isteri itu) menangguhkan dirinya (ber'iddah) empat bulan sepuluh hari. Kemudian apabila telah habis 'iddahnya, maka tiada dosa bagimu (para wali) membiarkan mereka berbuat terhadap diri mereka menurut yang patut. Allah mengetahui apa yang kamu perbuat.

${ }^{18}$ Nikah sirri menurut Imam Ibnu Taymiyah : Nikah yang dilakukan tanpa wali dan saksi. Maka nikah sirri itu batal menurut ulama karena "tidak ada pernikahan kecuali dengan adanya wali. Ibnu taimiyah : hukum-hukum perkawinan penerjamah Rusnan Yahya, Jakarta 1997

${ }^{19}$ Ibid, hlm. 512

${ }^{20}$ Ibnu Hajar Al-Asqolani, Bulugh Al-Marom min Adhillatil Ahkam, Terjemah, Kitab Nikah. Shahih, Jakarta, 2016, Kitab Nikah. 
Akan tetapi, pada dasarnya ketentuan teks di atas terbatas bagi janda saja. Walaupun demikian dianjurkan untuk menghadirkan wali dan saksi baik untuk janda maupun buat yang gadis. Hal ini sejalan dengan firman Allah swt : Maka nikahilah wanita itu dengan izin keluarganya. (QS. An Nisa 25)

Ayat tersebut bisa menjadi pedoman kesempurnaan pernikahan yang dituntut, hukum Fiqh yang berlaku di Indonesia cenderung mensyaratkan adanya wali dan saksi dalam pernikahan. Dasarnya adalah teks-teks keagamaan (syari'at hukum Islam) yang menyatakan adanya wali dan juga saksi. Lantas bagaiman dengan pernikahan yang sudah dilaksanakan, tetapi para saksi diminta unruk merahasiakan akadnya atau tidak memberitahukan (mengumumkannya) kepada orang lain?

Dalam masalah ini ulama berbeda pendapat, seperti Imam Syafi'i dan Hanafi menilai akad itu tetap sah. Berarti pernikahannya sah akan tetapi makruh. Imam Malik menganggap dan para sahabatnya pernikahan yang dirahasiakan pasakh (batal). Dalam arti tidak sah dan harus diulang kembali disaksikan khalayak ramai serta disiarkan. Penulis berpendapat perbedaan pendapat ini dapat dianalisis dari fungsi saksi itu sendiri. Apakah saksi itu hanya sebagai rukunnya saja, atau kesaksiannya itu bertujuan untuk menutup kemungkinan perselisihan yang terjadi.

Kesaksian dalam pernikahan dalam Al Qur"an tidak secara jelas diungkapkan, namun secara ekspelisit banyak seperti dalam bermu'amalah dan lain sebaginya. Dalam KHI pasal 24 ayat (1) menyebutkan : Saksi dalam perkawinan merupakan rukun pelaksanaan akad nikah. (2) Setiap perkawinan harus disaksikan oleh dua orang saksi. Dan pasal pasal 26 : Saksi harus hadir dan menyaksikan secara langsung akdan nikah serta menandatangani Akta Nikah pada waktu dan ditempat akad nikah dilangsungkan. ${ }^{21}$

Dari sini ditegaskan bahwa pernikahan dianggap sah jika sudah melengkapi syarat dan rukunnya. Sebagaimana dalam Kompilasi Hukum Islam (KHI) disebutkan pada Pasal 14 Untuk melaksanakan perkawinan harus ada :

1. Calon Suami

2. Calon Isteri

3. Wali nikah

4. Dua orang saksi, dan

5. Ijab dan Kabul.

Pernikahan bagi umat Islam merupakan ikatan lahir batin antara seorang laki-laki dan seorang perempuan sebagai suami isteri berdasar akad nikah yang sesuai dengan syarie at Islam, dengan tujuan membentuk keluarga sakinah atau rumah tangga yang bahagia sesuai hukum Islam. Pernikahan adalah ikatan yang sangat kuat yang dikenal dalam islah dengan istilah mitsaqon ghalidhan untuk mentaati perintah Allah dan melaksanakannya merupakan ibadah. Oleh karena itu, untuk menjaga kesucian lembaga perkawinan itu, maka perkawinan atau pernikahan bagi umat Islam hanya sah apabila dilakukan menurut hukum Islam dan keberadaannya perlu dilindungi oleh hukum negara. ${ }^{22}$

Dalam konteks nikah sirri adalah pilihan hukum yang didasarkan hanya kepada konteks agama, yang penekanan esensinya tidak sekedar hubungan hukum

\footnotetext{
${ }^{21}$ Kompilasi Hukum Islam

22 Mochamad Sodiq : Telaah Ulang Wacana Seksualitas, Yogyakarta: PSW UIN SuKa, 2004
} 
saja, tapi lebih kepada faktor konsekuensi pengamalan ibadah kepada Allah SWT. Meskipun demikian perlu juga memerhatikan aspek social yakni mengumumkan pernikahan kepada khalayak ramai.

Nikah siri dikenal setelah ada negara/pemerintahan yang mengharuskan pencatatan secara administratif. Sebab pemerintah menganggap orang yang tidak melakukan pencatatan nikah, maka itu digolongkan sebagai nikah siri. Dari sini Penulis secara pribadi memahami bahwa sekiranya tidak ada aturan negara tentang kewajiban pencatatan nikah maka mungkin tidak dikenal yang namanya nikah siri. dan permaslahan harta gono gini, hadhanah (hak asuh) dan lain sebagainya hanya diselesaikan dalam satu kesepakatan saja.

Istilah nikah siri atau nikah yang dirahasiakan itu sendiri memang sudah dikenal di kalangan para ulama. Akan tetapi, nikah siri yang dikenal pada masa dahulu berbeda pengertiannya dengan nikah siri yang jumpai saat ini. Dahulu yang dimaksud dengan nikah siri yaitu nikah yang sesuai dengan rukun-rukun nikah dan syaratnya menurut syari'at, hanya saja saksi diminta tidak memberitahukan terjadinya pernikahan itu kepada khalayak ramai, maupun kepada masyarakat,dalam arti tidak ada walimah al-'Ursy.

Penulis berpendapat pernikahan yang dilakukan secara hukum Islam yakni, sesuai dengan rukun dan syaratnya maka pernikahannya sah. hanya saja perlu dilakukan diumumkan untuk menghilangkan pitnah dan tanggapan yang negatif dari masyarakat. Berdasarkan hadist nabi:

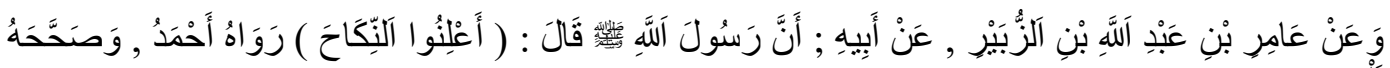

Dari Amir Ibnu Abdullah Ibnu al-Zubair, dari ayahnya Radliyallaahu 'anhu bahwa Rasulullah Shallallaahu 'alaihi wa Sallam bersabda: "Sebarkanlah berita pernikahan." Riwayat Ahmad. (Hadits shahih menurut Hakim) ${ }^{23}$

Di kalangan ulama sendiri, nikah siri ini masih diperdebatkan, dalam menetapkan pernikahan yang dilakukan secara nikah siri itu sah atau tidak. Hal ini dikarenakan masih banyak ulama dan juga sebagaian masyarakat yang mengatakan bahwa nikah siri lebih baik dari perzinahan. Padahal kalau dilihat dari berbagai kasus yang ada, nikah siri juga tampaknya lebih banyak menimbulkan kemudharatan dari pada manfaatnya.

\section{Hukum Nikah Siri Menurut Perspektif Hukum Positif Indonesia}

Secara literal Nikah Sirri berasal dari bahasa Arab yang terdiri dari dua kosa kata yaitu "nikah" dan "sirri". Nikah yang menurut bahasa artinya mengumpulkan, saling memasukkan, dan digunakan untuk arti bersetubuh (wathi). Kata "nikah" sering dipergunakan untuk arti persetubuhan (coitus), juga untuk arti akad nikah. Sedangkan kata Sirri berasal dari bahasa Arab "Sirr" yang berarti rahasia. $^{24}$

Dengan demikian beranjak dari arti etimologis, nikah sirri dapat diartikan sebagai pernikahan yang rahasia atau dirahasiakan. Dikatakan sebagai pernikahan yang dirahasiakan karena prosesi pernikahan semacam ini sengaja disembunyikan dari public dengan berbagai alasan, dan biasanya hanya dihadiri oleh kalangan

\footnotetext{
${ }^{23}$ Ibnu Hajar Al-Asqolani, Bulughul Marom min Adhillatil Ahkam, Terjemah, Kitab Nikah. Shahih, Jakarta, 2016, Kitab Nikah

${ }^{24}$ Abd.Rahman Gazaly, Fiqh Munakahat, Jakarta, Kencana, 2006
} 
terbatas keluarga dekat, tidak dimeriahkan dalam bentuk resepsi walimatul ursy secara terbuka untuk umum.

Jika kita berpedoman dari pengertian etimologis nikah sirri sebagaimana tersebut di atas, maka setidaknya ada 3 (tiga) bentuk atau model nikah sirri yang dilakukan dalam masyakat, yaitu:

Pertama : Pernikahan antara seorang pria dengan seorang wanita yang sudah cukup umur yang dilangsungkan di hadapan petugas negara serta dicatat oleh Pegawai Pencatat Nikah namun hanya dihadiri oleh kalangan terbatas keluarga dekat, tidak diumumkan dalam suatu resepsi walimatul ursy.

Kedua : Pernikahan antara seorang pria dan seorang wanita yang masih di bawah umur menurut undang-undang, kedua-duanya masih bersekolah. Pernikahan ini datang atas inisiatif dari orang tua kedua belah pihak calon suami dan isteri yang sepakat menjodohkan anak-anak mereka dengan tujuan untuk lebih memastikan perjodohan dan menjalin persaudaraan yang lebih akrab. Biasanya dalam pernikahan setelah akad nikah mereka belum kumpul serumah dulu. Setelah mereka tamat sekolah dan telah mencapai umur perkawinan, lalu mereka dinikahkan lagi secara resmi di hadapan PPN/KUA yang menurut istilah jawa disebut "munggah".

Ketiga : model pernikahan antara seroang pria dan seroang wanita yang sudah cukup umur menurut undang-undang akan tetapi mereka sengaja melaksanakan perkawinan ini di bawah tangan (nikah siri), tidak dicatatkan di KUA dengan berbagai alasan. Pernikahan ini mungkin terjadi dengan alasan menghemat biaya, yang penting sudah dilakukan menurut agama sehingga tidak perlu dicatatkan di KUA. Atau mungkin, pernikahan itu dilakukan oleh seseorang yang mampu secara ekonomi, akan tetapi karena alasan tidak mau repot dengan segala macam urusan administrasi dan birokrasi, atau karena alasan lain maka ia lebih memilih nikah sirri saja. ${ }^{25}$

Dari tiga model pernikahan sirri tersebut di atas, pernikahan sirri model terakhir adalah yang paling relevan dengan topic bahasan dalam tulisan ini. Dengan demikian, yang dimaksud dengan Nikah Sirri dalam tulisan ini ialah suatu pernikahan yang berlangsung yang tidak dicatatkan di Kantor Urusan Agama atau dengan kata lain disebut dengan Nikah siri (bawah tangan).

Dalam sistem peraturan perundang undangan yang berlaku di Indonesia, nikah siri merupakan perkawinan yang tidak memiliki asas legalitas hukum, dalam arti tidak sesuai dengan aturan perundang-undangan yang ada. Hal ini didasarkan pada UU No 1/1974 tentang Perkawinan, pasal 2 ayat (1 dan 2) jo KHI pasal 4, yaitu : (1) Perkawinan sah apabila dilakukan menurut hukum masingmasing agama dan kepercayaannya itu. (2) Tiap-tiap perkawinan dicatat menurut peraturan perundang-undangan yang berlaku. ${ }^{26}$

Kemudian KHI pasal 5 ayat (1 dan 2) yaitu : (1) Agar terjamin ketertiban perkawinan bagi masyarakat Islam setiap perkawinan harus dicatat. (2) Pencatatan perkawinan tersebut apada ayat (1), dilakukan oleh Pegawai Pencatat Nikah sebagaimana yang diatur dalam Undang-undang No.22 Tahun 1946 jo Undangundang No. 32 Tahun 1954 jo UU No 1/1974.

Bahkan, masalah pencatatan perkawinan ke KUA sebagaimana dimaksud dalam pasal 2 ayat (2) jo. KHI pasal 5 ayat (ayat 1 dan 2) merupakan syarat sahnya perkawinan dalam hukum positif di Indonesia, bukan hanya sebatas dalam

\footnotetext{
${ }^{25} \mathrm{http} / / /$ www.pa-rembang.go.id/berita-artikel/artikel-hukum.html

${ }^{26}$ UU No $1 / 1974$ tentang Perkawinan
} 
hubungan administrasi saja. Pernyataan ini didasarkan pada KUHAPerdata pasal 81 yang berbunyi : Tidak ada upacara keagamaan yang boleh diselenggarakan, sebelum kedua pihak membuktikan kepada pejabat agama mereka bahwa perkawinan di hadapan Pegawai Catatan Sipil telah berlangsung. ${ }^{27}$

Pernyataan diatas ditegaskan lagi dalam Peraturan Pemerintah No 9 tahun 1975 sebagai pelaksanaan UU Perkwinan pasal 3 ayat (1, 2 dan 3) sebagi berikut : (1) Setiap orang yang akan melangsungkan perkawinan memberitahukan kehendaknya itu kepada Pegawai Pencatat ditempat perkawinan akan dilangsungkan. (2) Pemberitahuan tersebut dalam ayat (1) dilakukan sekurangkurangnya 10 (sepuluh) hari kerja sebelum perkawinan dilangsungkan. (3) Pengecualian terhadap jangka waktu tersebut dalam ayat 1 disebabkan sesuatu alasan yang penting, diberikan oleh Camat atas nama Bupati Kepala Daerah. ${ }^{28}$

Dalam suatu perkawinan harus dilakukan secara sah menurut hukum agama, akan tetapi juga harus dicatat oleh pejabat yang berwenang, supaya sah perkawinan itu secara negara. Dalam arti sesuai dengan aturan perundangundangan yang ada dan memiliki legalitas yang dapat dipertanggung jawabkan. Dengan demikian, dalam perspektif peraturan perundang-undangan, nikah sirri adalah pernikahan yang tidak mempunyai kekuatan hukum. Perkawinan yang tidak memiliki kekuatan hukum berdampak yuridis terhadap hak-hak pelayanan publik oleh instansi yang berwenang bagi pelakunya. Mereka tidak memperoleh perlindungan dan pelayanan hukum oleh instansi yang berwenang sebagaimana mestinya. Perkawinan mereka tidak diakui dalam daftar kependudukan, bagi anak-anak mereka tidak dapat memperoleh akte kelahiran dan lain sebagainya. Dengan kata lain, pernikahan sirri banyak membawa madharat dalam kehidupan bermasyarakat, berbangsa dan bernegara. Sedangkan mencatatkan perkawinan lebih banyak mendatangkan manfaat bagi masyarakat dan bangsa.

\section{Perkembangan hukum nikah siri menurut perspektif hukum Islam dan hukum positif Indonesia}

Nikah sirri adalah nikah secara rahasia (sembunyi-sembuyi). Disebut secara rahasia karena tidak dilaporkan ke Kantor Urusan Agama (KUA) bagi muslim atau ke Kantor Catatan Sipil bagi non-muslim. Dalam Undang-undang RI No.1 Tahun 1974 tentang Perkawinan disebutkan bahwa:

"Nikah adalah ikatan lahir batin antara seorang pria dengan seorang wanita sebagai suami isteri dengan tujuan membentuk keluarga (rumah tangga yang bahagia dan kekal berdasarkan Ketuhanan Yang Maha Esa.” Sedangkan dalam hukum Islam nikah adalah ijab dan qabul ('aqad) yang menghalalkan persetubuhan antara lelaki dan perempuan yang diucapkan oleh kata-kata yang menunjukkan nikah.

Dari pengertian di atas penulis dapat memahami bahwa pernikahan baru dianggap sah jika dilakukan dengan aqad yang mencakup ijab dan qabul antara wanita yang dilamar dengan laki-laki yang melamarnya. Dilakukan secara terangterangan maupun secara sembunyi-sembunyi tetap sah jika sudah memenuhi syarat dan rukun nikah.

Dari nikah itu berakibat adanya hak dan kewajiban antara suami istri serta bertujuan mengadakan pergaulan yang dilandasi tolong-menolong, di samping itu juga bertujuan sebagai sarana untuk menghasilkan keturunan yang dapat

\footnotetext{
${ }^{27}$ KUHAPERDATA Pasal 81

${ }^{28}$ PP No 9 tahun 1975 tentang Pelaksanaan UUP
} 
menjamin kelangsungan eksistensi manusia di permukaan bumi. ${ }^{29}$ Lebih dari itu, ajaran Islam dengan seperangkat aturannya, nikah bertujuan untuk meraih keteraturan dalam berketurunan dalam rangka menjaga harkat dan martabat kemuliaan manusia dan hal ini merupakan salah satu dari tujuan Islam diturunkan.

Begitu mulianya pernikahan itu sehingga diatur sedemikian rupa, baik oleh agama maupun oleh negara, walaupun sampai hari ini masih dijumpai pelanggaran-pelanggaran yang secara sadar atau tidak dilakukan oleh sebagian masyarakat, khususnya umat Islam mengenai nikah siri dan berbagai bentuk penyimpangan dan pelanggaran lainnya terhadap sistem nikah khususnya di Indonesia seperti nikah usia dini dan nikah kontrak.

Indonesia sebagai negara hukum, tidak luput mengatur rakyatnya dalam hal perkawinan. Walaupun Indonesia bukanlah negara yang hukumnya berdasarkan hukum Islam, akan tetapi hukum Islam memiliki tempat khusus utamanya dalam aturan pernikahan. Sistem peraturan perundang-undangan yang berlaku di Indonesia tidak mengatur nikah siri. Jadi nikah siri merupakan perkawinan yang tidak memiliki asas legalitas atau payung hukum, dalam arti tidak sesuai dengan aturan perundang-undangan yang ada. Hal ini didasarkan pada UU No 1/ 1974 tentang Perkawinan, pasal 2 ayat (1 dan E jo KHI pasal 4, yaitu : (1) Perkawinan sah apabila dilakukan menurut hukum masing-masing agama dan kepercayaannya itu. (2) Tiap-tiap perkawinan dicatat menurut peraturan perundang-undangan yang berlaku. Dan KHI pasal 5 ayat (1 dan 2) yaitu : (1) Agar terjamin ketertiban perkawinan bagi masyarakat Islam setiap perkawinan harus dicatat. (2) Pencatatan perkawinan tersebut apada ayat (1), dilakukan oleh Pegawai Pencatat Nikah sebagaimana yang diatur dalam Undangundang No.22 Tahun 1946 jo Undang-undang No. 32 Tahun 1954 jo UU No $1 / 1974$.

Dari penjelasan diatas sudah sangat jelas bahwa nikah siri merupakan pernikahan yang illegal wedding, salah seorang pakar hukum Islam mengatakan : kawin liar atau yang biasa disebut nikah siri tidak sah dan batal demi hukum, karena tidak mempunyai kepastian hukum dan buku nikah serta sulit menjamin keabsahannya, menurut hukum Syari'at agama sering terjadi manipulasi identitas karena biasanya pelaksanaan kawin liar itu melalui penghulu gadungan. ${ }^{30}$

Menurut penulis suatu perkawinan harus dilakukan secara sah menurut hukum agama, akan tetapi juga harus dicatat oleh pejabat yang berwenang, supaya sah perkawinan itu secara negara. Dalam arti sesuai dengan aturan perundang-undangan yang ada dan memiliki legalitas yang dapat dipertanggung jawabkan. Dengan demikian, dalam perspektif peraturan perundang-undangan, nikah sirri adalah pernikahan yang tidak mempunyai kekuatan hukum. Perkawinan yang tidak memiliki kekuatan hukum berdampak yuridis terhadap hak-hak pelayanan publik oleh instansi yang berwenang bagi pelakunya. Bagi sebagian pelaku nikah siri tidak memperoleh perlindungan dan pelayanan hukum oleh instansi yang berwenang sebagaimana mestinya. Perkawinan mereka tidak diakui dalam daftar kependudukan, bagi anak-anak mereka tidak dapat memperoleh akte kelahiran dan lain sebagainya. Dengan kata lain, pernikahan sirri banyak membawa madharat dalam kehidupan bermasyarakat, berbangsa dan

${ }^{29}$ Abdul Azis Dahlan, et.al., Ensiklopedi Hukum Islam, Jilid IV (Cet. I; Jakarta: Ichtiar Baru Van Hoeve, 1996

${ }^{30}$ Nurul Huda Haem: Awas Illegal Wedding, Jakarta : Mizan publika, 2007. Hal 11 
bernegara. Sedangkan mencatatkan perkawinan lebih banyak mendatangkan manfaat bagi masyarakat dan bangsa.

A. Faktor-faktor terjadinya nikah siri

Secara umum nikah sirri dapat disebabkan oleh beberapa faktor, yaitu:

1. Kurangnya Kesadaran dan Pemahaman Hukum Masyarakat

Masih banyak di antara masyarakat kita yang belum menyadari dan memahami sepenuhnya betapa pentingnya pencatatan perkawinan. Kalaupun dalam kenyataannya perkawinan itu dicatatkan di KUA sebagian dari mereka boleh jadi hanya sekedar ikut-ikutan belaka. Atau mungkin mereka menganggapnya sebagai tradisi yang lazim dilakukan oleh masyarakat setempat. Barangkali pencatatan perkawinan itu hanya dipandang sekedar soal administrasi, belum dibarengi dengan kesadaran sepenuhnya akan segi-segi manfaat dari pencatatan perkawinan tersebut. Padahal pencatatan perkawinan yang merupakan perintah undang-undang itu sesungguhnya mempunyai tujuan penting, yakni proses dokumentasi atas perbuatan hukum perkawinan itu sendiri sehingga kemudian akan memberikan perlindungan hukum bagi suami isteri yang bersangkutan beserta anak turunnya di kemudian hari, sehingga dimulai dari terbentuknya keluarga sebagai unit masyarakat terkecil yang tertib hukum akan tercipta kehidupan masyarakat bangsa yang madani.

Permasalahannya ialah, mengapa begitu rendah kesadaran dan pemahaman hukum sebagian masyarakat Indonesia dalam hal pencatatan perkawinan dan bagaimana upaya kita untuk meningkatkan kesadaran hukum bagi mereka. Semua itu tentu merupakan tanggung jawab bersama antara pemerintah yang memposisikan dirinya sebagai Negara hukum dan keseluruhan bangsa Indonesia sebagai masyarakat hukum. Jika suatu kelompok masyarakat dalam suatu wilayah hukum di Indonesia belum mempunyai kesadaran dan pemahaman hukum yang tinggi, hal ini tentu bukan semata-mata kesalahan masyarakat itu sendiri melainkan juga disebabkan kurang maksimalnya peran dan upaya lembaga pemerintahan yang terkait dalam memberikan edukasi terhadap masyarakat tentang betapa pentingnya mencatatkan perkawinan mereka.

2. Sikap Apatis Sebagian Masyarakat terhadap Hukum

Sebagian masyarakat ada yang bersikap masa bodoh terhadap ketentuan peraturan yang menyangkut perkawinan. Kasus pernikahan Syekh Puji dengan perempuan di bawah umur bernama Ulfah dan kasus pernikahan sirri Aceng Fikri, mantan Bupati Garut, sebagaimana terkuak di media massa merupakan contoh nyata sikap apatis masyarakat terhadap keberlakuan hukum Negara. Dari pemberitaan media massa tersebut, dapat kita pahami terdapat dua hal yang diabaikan oleh Syekh Puji maupun Aceng Fikri yaitu,

Pertama: Pernikahan tersebut merupakan poligami yang tidak melalui izin di pengadilan, Kedua: Dalam kasus pernikahan sirri Syekh Puji, beliau tidak mau mengajukan permohonan dispensasi kawin meskipun calon isteri tersebut masih di bawah umur menurut undang-undang perkawinan.

Sikap apatisme semacam itu, terutama yang dilakukan oleh publik figur, sungguh merupakan hambatan besar bagi terlaksananya keberlakuan hukum. Karena apa yang dilakukan oleh seorang tokoh masyarakat, biasanya akan dicontoh oleh mereka yang mengidolakannya. Oleh karena itu penanganan secara hukum atas kasus yang dilakukan Syekh Puji dan Aceng Fikri sungguh sangat tepat, agar tidak menimbulkan citra buruk bagi bangsa Indonesia yang saat ini 
sedang berusaha memposisikan supremasi hukum dalam sebuah Negara hukum yang bernama Indonesia.

3. Ketentuan Pencatatan Perkawinan Yang Tidak Tegas

Sebagaimana kita ketahui, ketentuan pasal 2 UU No.1 / 1974 merupakan azas pokok dari sahnya perkawinan. Ketentuan ayat (1) dan (2) dalam pasal tersebut harus dipahami sebagai syarat komulatif, bukan syarat alternative sahnya suatu perkawinan. Dari norma hukum tersebut sebenarnya sudah cukup menjadi dasar bagi umat Islam terhadap wajibnya mencatatkan perkawinan mereka. Akan tetapi ketentuan tersebut mengandung kelemahan karena pasal tersebut multi tafsir dan juga tidak disertai sanksi bagi mereka yang melanggarnya. Dengan kata lain ketentuan pencatatan perkawinan dalam undang-undang tersebut bersifat tidak tegas dan ambigu. Karena Itu rasanya perlu dilakukan revisi terhadap UUP agar tidak menyebabkan kebimbangan dalam menafsirkannya maupun menerapkannya. Dalam Pasal 4 RUU tersebut menegaskan bahwa: setiap perkawinan wajib dicatat oleh PPN/KUA berdasarkan peraturan perundangundangan yang berlaku. Kemudian pasal 5 ayat (1) menyatakan: untuk memenuhi ketentuan pasal 4, setiap perkawinan wajib dilangsungkan di hadapan PPN/KUA. ${ }^{31}$ Kewajiban pencatatan sebagaimana ketentuan pasal 4 dan pasal 5 ayat (1) tersebut disertai ancaman pidana bagi yang melanggarnya.

Akan tetapi, Ketentuan pidana yang menyangkut pelanggaran pencatatan perkawinan tersebut dinyatakan dalam Pasal 141 RUU tersebut menyebutkan: setiap orang yang dengan sengaja melangsungkan perkawinan tidak di hadapan PPN/KUA sebagaimana dimaksud dalam Pasal 5 (1) dipidana dengan pidana denda paling banyak 6.000.000,- (enam juta rupiah) atau hukuman kurungan paling lama 6 (enam) bulan.

Pasal 145 RUU menyatakan: PPN yang melanggar kewajibannya sebagaimana dimaksud dalam pasal 4 dikenai hukuman kurungan paling lama 1 (satu) tahun atau denda paling banyak Rp 12.000.000,- (dua belas juta rupiah).

Pasal 146 RUU menyatakan: setiap orang yang melakukan kegiatan perkawinan dan bertindak seolah-olah sebagai PPN dan/atau wali hakim sebagaimana dimaksud dalam pasal 4 dan pasal 21 dipidana penjara paling lama 3 (tiga) tahun.

Dengan demikian, ketidaktegasan ketentuan pencatatan dalam undangundang yang berlaku selama ini masih memberi ruang gerak yang cukup luas bagi pelaksanaan nikah siri bagi sebagian masyarakat yang melakukannya. Hal ini juga menjadi salah satu factor penyebab terjadinya pernikahan sirri.

4. Sulitnya Izin Poligami

Dalam UU No.1/1974 konsep perkawinan di Indonesia menganut azas monogami, meskipun masih diberikan peluang untuk berpoligami, sebagaimana diatur dalam pasal 4 UUP. Yaitu :

Ayat (1) Dalam hal seorang suami akan beristri lebih dari seorang, sebagaimana tersebut dalam pasal 3 ayat (2) Undang-undang ini, maka ia wajib mengajukan permohonan ke Pengadilan di daerah tempat tinggalnya.

Ayat (2) Pengadilan dimaksud dalam ayat (1) pasal ini hanya memberi izin kepada suami yang akan beristri lebih dari seorang apabila :

a. Istri tidak dapat menjalankan kewajibannya sebagai isteri

b. Istri mendapat cacat badan atau penyakit yang tidak dapat disembuhkan

c. Istri tidak dapat melahirkan keturunan.

\footnotetext{
${ }^{31}$ UU No.1 Tahun 1974 Perkawinan
} 
Dan Pasal 5 Ayat (1) Untuk dapat mengajukan permohonan ke Pengadilan sebagaimana dimaksud dalam pasal 4 ayat (1) Undang-undang ini harus memenuhi syarat-syarat berikut:

1. Adanya persetujuan dari isteri/ isteri-isteri

2. Adanya kepastian bahwa suami mampu menjamin keperluan-keperluan hidup isteri-isteri dan anak-anak mereka.

3. Adanya jaminan bahwa suami akan berlaku adil terhadap isteri-isteri dan anak-anak mereka.

Ayat (2) Persetujuan yang dimaksud dalam ayat (1) huruf (a) pasal ini tidak diperlukan bagi seorang suami apabila isteri/isteri-isterinya tidak mungkin dimintai persetujuannya dan tidak dapat menjadi pihak dalam perjanjian;atau apabila tidak ada kaber dari istrinya selama sekurang-kurangnya 2 (dua) tahun atau karena sebab-sebab lainnya yang perlu mendapat penilaian dari Hakim Pengadilan.

\section{KESIMPULAN}

Suatu perkawinan yang dilakukan sah menurut hukum agama, apabila sesuai dengan rukun dan syarat nikah. Begitu juga dengan pernikahan yang dilakukan secara rahasia (nikah siri) dalam pengertian piqh Indonesia. Berbeda dengan nikah siri pada zaman dahulu yang mana jumhur ulama melarang pernikahan yang dilakukan secara rahasia. Berdasarkan hadist nabi yang menganjurkan ummatnya supaya mengumumkan pernikahan.

Pencatatan perkawinan dalam hukum Islam merupakan suatu syarat yang melengkapi keabsahan suatu pernikahan. Hal ini merupakan analogi (qiasan) dari hukum pencatatan jual beli dalam mua'amalah, serta termasuk dari bagian maqosyidu syari'ah yaitu hifh zul nasl.

Dalam perspektif hukum positif Indonesia, menurut peraturan perundangundangan, nikah sirri merupakan pernikahan yang tidak asas legalitas. Dalam arti tidak mempunyai kekuatan hukum. Perkawinan yang tidak memiliki kekuatan hukum berdampak yuridis terhadap hak-hak pelayanan publik oleh instansi yang berwenang bagi pelakunya. Mereka tidak memperoleh perlindungan dan pelayanan hukum oleh instansi yang berwenang sebagaimana mestinya. Perkawinan mereka tidak diakui dalam daftar kependudukan, bagi anak-anak mereka tidak dapat memperoleh akte kelahiran dan lain sebagainya. Dengan kata lain, pernikahan sirri banyak membawa madharat dalam kehidupan bermasyarakat, berbangsa dan bernegara. Sedangkan mencatatkan perkawinan lebih banyak mendatangkan manfaat bagi masyarakat dan bangsa

Nikah siri sering kita jumpai di tengah-tengah masyarakat kita, hal ini terjadi karena berbagai alasan. Secara umum nikah siri dapat terjadi karena :

1 Kurangnya Kesadaran dan Pemahaman Hukum Masyarakat

2 Sikap Apatis Sebagian Masyarakat Terhadap Hukum

3 Ketentuan Pencatatan Perkawinan Yang Tidak Tegas

4 Sulitnya Izin Poligami

5 Faktor usia serta Hamil diluar nikah

6 Beda agama 


\section{DAFTAR PUSTAKA}

Abd. Rahman Gazaly, Fiqh Munakahat, Jakarta, Kencana, 2006

Abdul Azis Dahlan, et.al., Ensiklopedi Hukum Islam, Jilid IV (Cet. I; Jakarta: Ichtiar Baru Van Hoeve, 1996

Ahmad Azhar Basyid : Hukum Perkawinan Islam, cetakan 12 Yogyakarta, 2010

Ali Yusuf As-Subki, Ali Yusuf : Fiqh Keluarga, "Pedoman Berkeluarga dalam Islam", Jakarta 2010.

Aris Sugianto: Nikah Bawah Tangan, Jakarta 2005

Departemen Pendidikan Nasional, Kamus Besar Bahasa Indonesia, Edisi Ketiga, Jakarta, Balai Pustaka, 2001

Happy Susanto: Nikah Sirri Apa Untungnya?. Jakarta: Visi Media, 2007

Ibnu Hajar Al-Asqolani, Bulugh Al-Marom min Adhillatil Ahkam, Terjemah, Kitab Nikah. Shahih, Jakarta, 2016, Kitab Nikah

K.H. Ibrahim Husen : Membina Keluarga Bahagia, Bab 4 Konsepsi Pembentukan Keluarga Bahagia dalam Islam. Jakarta, 1993

Mochamad Sodiq : Telaah Ulang Wacana Seksualitas, Yogyakarta: PSW UIN SuKa, 2004

Mukhtar Kamal : “Asas-asas Hukum Islam tentang Perkawinan”, Jakarta 1974.

Musthafa Luthfi dan Mulyady Luthfy : Nikah Sirri, Surakarta 2010.

Nurul Huda Haem: Awas Illegal Wedding, Jakarta : Mizan Publika, 2007

Sekh Muhammad bin Ibrahim at-Tuaijri : Ringkasan Fikih Islam, terjemahan Team Indonesia Islam house.com, 2009

Sekh Muhammad bin Ibrahim at-Tuaijri: Ringkasan Fikih Islam, terjemahan team Indonesia Islam house.com, 2009

Suharsimi Arikunto: Prosedur Penelitian, Yogyakarta 2010

\section{Undang-undang dan Peraturan Hukum:}

UU No 1 Tahun 1974 tentang Perkawinan

PP No 9 tahun 1975 tentang Pelaksanaan UUP

Kompilasi Hukum Islam

KUHA PERDATA Pasal 81

\section{Website:}

https://detil.co/hadis-pernikahan-yang-perlu-diketahui. Diunduh tgl 08/03/2021 jam 9;30

http://www.pa-rembang.go.id/9-artikel/90-fenomena-nikah-sirri-dalam-sebuahnegara-hukum-indonesia-dewasa-ini.html

http://www.pa-rembang.go.id/berita-artikel/artikel-hukum.html 